Bull. Fac. Agric., Cairo Univ.,64:437-443 (2013).

\title{
EFFECT OF TILLAGE PRACTICES AND MULCHING ON GROWTH AND YIELD OF SQUASH (Cucurbita pepo) GROWN UNDER RAIN-FED CONDITIONS IN SEMI-ARID REGION
}

\author{
(Received:6.12.2013) \\ By \\ A.Y. Mahadeen \\ Plant Production Department, Faculty of Agriculture, Mu'tah University, Al-Karak, Jordan
}

\begin{abstract}
A field experiment was carried out during 2009-2010 growing season, at the Agricultural Research Station, Mu'tah University, Jordan; to study the effects of mulching and tillage on growth, yield, and quality of squash (Cucurbita pepo, var. melopepo) under rain-fed conditions of Jordan. The trial was laid out in split plot arrangement with a randomized complete block design with 3 replicates. Tillage treatments were assigned in the main plots and mulch treatments in the sub-plots. The field was divided into three blocks assigned to tillage times (T1, T2 and T3). T1: tillage was done only once during early spring; T2: tillage was done twice and T3: tillage was done three times. Soil cover treatments (black plastic mulch or no mulch) were distributed randomly according to split plot arrangement with a randomized complete block design.

Squash yields (early, mid and late) were higher when the soil was tilled three times (T3) and covered with BP mulch compared with other treatment combinations. Covering the soil surface with plastic mulch had pronounced positive effect on yield of squash compared with bare soil. Fruit number and average fruit weight had the same trends as fruit yield. Fresh weight of squash plants at the end of the growing season tended to be higher when the soil was tilled three times and covered with BP mulch. Plots covered with BP mulch produced higher fresh and dry weights.

In general, soil moisture contents after one month after planting were higher when the soil plowed three times (T3) compared with (T2 and T1). Non-mulched plots had the lower SMC than black plastic mulched plots.

It is concluded that using black plastic mulch as soil covering enhanced squash vegetative growth and yield. Also, tillage the soils three times and using black plastic mulch produced high squash yield under rain-fed conditions.
\end{abstract}

Key words: Cucurbita pepo, plastic mulch, squash, tillage.

\section{INTRODUCTION}

Jordan has a Mediterranean climate characterized by long, hot, dry summers and short, cool, rainy winters (Department of Metrology, 1997). Water is scarce and the demand is always increasing to meet the needs of modern irrigated agriculture. With rapidly growing population and expanding economy, optimal water management is a priority. Over $90 \%$ of Jordan area receives annual rainfall not exceeding $200 \mathrm{~mm}$ and only $4 \%$ of the area receives $>350 \mathrm{~mm}$ of annual rainfall, most of which evaporates back to atmosphere. The available volume of water in near future will not cover the total water need for domestic, industrial and agricultural use. In addition, the pattern of rainfall is characterized by uneven distribution and strong fluctuation from year to year in terms of quantity and timing. These prevailing conditions during the past 4 decades resulted in a dramatic reduction in planting summer vegetables such as cucurbits, okra and tomato under rain-fed conditions of Jordan. Therefore, low soil moisture content in the root zone usually limits productivity of rain-fed summer crops in Jordan.

Improving productivity of rain-fed summer crops in dry season can be enhanced by conserving moisture that has accumulated in the root zone during the previous rainy season. Soil management practices such as tillage practices and mulching have been suggested by several authors Hatami et al., 2012; Mamkagh, 2009; Mondal et al., 2008; (Anikwe et al., 2007; Kouwenhoven et al., 2002; Mohler, and Callaway, 1995) Khatibu et 
al., 1984; through improving water and nutrient uptake under drought conditions. Mulching is associated with yield increases for many vegetables (Berihun 2011; Hatami et al., 2012; Mamkagh, 2009) and improving soil moisture regime by reducing evaporation from the soil surface (Anikwe et al., 2007; Hatami et al. 2012; Mamkagh, 2009; Singh and Kamal, 2012), and water retention (Anikwe et al., 2007; Bhagat and Acharya, 1987; Jones, 2000; Jones and Sing, 2000). Mamkagh (2009) indicated that covering soil surface with plastic mulch reduced soil water evaporation and thus helps in retaining soil water. In Jordan, mulching has been practiced for several decades, but it has been done mostly in the production of vegetables under irrigation. This technique also might be introduced in the production of summer vegetables under rain-fed conditions.

Tillage practices are critical components of soil management systems (Mosaddeghi et al., 2009). The selection of an appropriate tillage practice for the production of crops is very important for optimum growth and yield (Aikins and Afuakwa, 2010). The yield increase was correlated with an increase in water contents in the soil due to reduced evaporation (Hatami et al., 2012; Khurshid et al., 2006; Mamkagh, 2009; Singh and Kamal, 2012). Among the crop production factors, tillage contributes up to $20 \%$ (Khurshid et al., 2006). Tillage plays a vital role in conservation of soil moisture at different depths in rain fed cultivation. It also improves soil conditions by altering the mechanical impedance to root penetration, hydraulic conductivity and holding capacity, which in turn affects plant growth (De Costa et al., 1997; Gupta and Gupta, 1986; Pilbeam et al., 1991; Thompson and Taylor, 1982; Varco et al., 1989). However, effects of tillage practices on vegetable crops have not been studied extensively. A few existing tillage studies indicated that most tillage benefits are directly related to soil moisture conservation and available moisture during the growing season (AbuHammad and Battikhi, 1995; Jones, 2000; Jones and Sing, 2000).

The present investigation was planned to determine the effect of different tillage practices in combination with mulching on growth and yield of summer squash under rain-fed conditions of Jordan highland.

\section{MATERIALS AND METHODS}

Experimental site:The experiment was conducted at the Research Station, Faculty of Agriculture,
Mutah University, Jordan during 2009/2010 summer growing season. The region has a Mediterranean climate (semi-arid, with cold rainy winters and hot dry summers) with annual mean rainfall of $350 \mathrm{~mm}$, most of rain fall occurs from December to February. During 2009/2010 season, the rainfall was $320 \mathrm{~mm}$. The soil of the experimental site is sand clay loam. Some soil physical and chemical properties of the experimental site are given in Table (1).

Soil sampling and analysis: Representative soil samples were taken from the experimental site to determine soil physical and chemical properties (Table 1). Between sowing and harvesting, the moisture levels in the soil were measured 3 times. The soil moisture was measured at 30,60 and 90 days up to $30 \mathrm{~cm}$ depth by gravimetric method (Black, 1965). The soil from 0-30 $\mathrm{cm}$ depth was sampled by manual coring and gravimetric moisture content $(\mathrm{g} / \mathrm{g})$ of the soil samples was calculated on oven dry weight basis and converted into volumetric moisture content $\left(\mathrm{cm}^{3} / \mathrm{cm}^{3}\right)$ and then expressed as profile water content in $0-30 \mathrm{~cm}$ soil depth.

Experimental design and treatments: The trial was laid out in split plot arrangement with a randomized complete block design with 3 replicates. Tillage treatments were placed in the main plots and mulch treatments in the sub-plots. The field was divided into three blocks which were assigned to tillage treatments ( $\mathrm{T} 1, \mathrm{~T} 2$ and T3) by using the traditional plow (disc plow). Tillage treatments were done from the end of the previous crop (wheat).

T1: spring tillage was done only during early spring before seed planting (25/3/2010).

T2: tillage was done two times; winter tillage $(10 / 12 / 2009)$ and spring tillage (early spring before seed planting 1/4/2010).

T3: tillage was done three times; summer tillage (after harvesting of the previous crop 1/8/2009), winter tillage (10/12/2009) and spring tillage (early spring before seed planting 1/4/2010).

All tillage treatments were followed by disking with a disc harrow to a depth of approximately $8 \mathrm{~cm}$ during spring to prepare seedbed.

Soil covering treatments: black plastic mulch (BP Mulch) or bare soil (No Mulch) were distributed randomly in sub-plots. Each sub plot consisted of 4 rows $2.40 \mathrm{~m}$ length. Inter- and intra- row spacing were $1.00 \mathrm{~m} \times 0.40 \mathrm{~m}$.

The experiment beds were prepared manually with traditional hoes. Black plastic-film $(100 \mathrm{~cm}$ wide and 125 micron thick) were used to cover the appropriate plots before planting (mid April) and 
two sides of the film were held down with soil. The squash (Cucurbita pepo) seeds were used. Seeds of squash (Anita hybrid cultivar) were planted on April 15, 2010.

Data collection: For fresh and dry weight, 4 plants were randomly selected, tagged and sampled. Fruits of each crop were harvested at the immature stage, counted and weighed. Fruit yield was separated into: early, mid, late and the total yield as well as fruit number were recorded. Squash was harvested from May, 31 to July, 19, 2010. Early yield started from May, 31 to June, 15; mid yield from June, 16 to June, 30 and late yield from July, 1 to the end of experiment.

MSTAT-C statistical package was used to analyze the data obtained from this experiment. Duncan's Multiple Ranges Test (DMRT) was used to determine the mean separations. The level of significance was calculated with an error probability of 0.05 (Steel and Torrie, 1980).

\section{RESULTS}

The soil moisture content (SMC) varied due to the experimental treatments. At 30 and 60 days after planting, there was a significant interaction between tillage practices and mulching for SMC at $30 \mathrm{~cm}$ depth (Table 2). Non-mulched plots had lower SMC than black plastic mulched (BP mulch) plots. The highest SMC (25.94) was observed at 30 days after planting in the plots tilled three times (T 3) and covered with BP mulch followed by plots tilled two times (T 2) and covered with BP mulch (23.27). At 60 days after planting, SMC was significantly the highest when plots covered with BP mulch regardless of tillage practices. In general, soil moisture content at 90 days after planting was not affected by different treatment combinations.

Date of squash seed germination was not significantly affected by tillage treatments and mulching treatments (Table 3). However, the earliest seed germination (about 11 days after seed planting) was achieved when the soil was covered with BP mulch. It appears that covering the soil with BP mulch had more pronounced effects on seed germination compared with tillage treatments. Also, the time of flowering was affected mainly by using BP mulch. Squash plants reached $50 \%$ flowering about 2 days earlier compared with non-mulched plots.

Fresh weight of squash plants at the end of the growing season tended to be higher when the soil tilled three times and covered with BP mulch compared with other treatment combinations
(Table 3). On the other hand, the lowest fresh weight was produced when the soil was tilled once in spring without using BP mulch. In general, plots covered with BP mulch produced higher fresh weight compared with uncovered plots. In general, covering the soil surface with BP mulch significantly increased the dry weight of squash compared with bare soil under different tillage treatments. While the highest dry weight of squash plants was obtained when the soil tilled twice $\left(T_{2}\right)$ and using BP mulch, the lowest fresh weight was obtained when the soil tilled only was once in the spring and non-mulched.

The data of effect of tillage practices and BP mulch on squash yield and its distribution (early, mid, late and total yield) are presented in Table (4). Early, mid and late squash yields were significantly higher when the soil was tilled three times (T3) and covered with BP mulch compared with other treatment combinations. Regardless of tillage practices, mulched plots significantly increased early, mid, late and the total yield of squash compared with bare plots. The present results indicated that plots tilled three times (T3) had the highest early, mid, late and total yield of squash, followed by tilled two times (T2) and followed by tilled one time (T1). While the highest total squash yield (27.9 ton $\left.^{\text {-ha }}\right)$ was produced when the soil tilled three times (T 3 ) and covered with BP mulch; the lowest total yield (7.6 ton $^{\text {-ha }}$ ) was produced when the soil was tilled once (T1) and no mulch. The same trends were also observed for early, mid and late yield.

The number of squash fruits (1000 fruit $\left.^{\text {-ha }}\right)$ is presented in Table (5). Soil tilled three times (T3) produced the highest number of squash fruits (early, med, late and total) compared with other tillage treatments. Also, covering the soils with plastic-film mulch significantly increased early, med, late and total fruit number compared with bare soil. It appears that plowing the soil three times (T 3) and covering with BP mulch produced the highest fruit numbers compared with other treatment combinations.

Average fruit weight of early yield was not significantly affected by different tillage time and soil covering treatment combinations (Table 6), however, significantly the lowest average of fruit weight $(92.8 \mathrm{gm})$ was produced when the soil was tilled one time during spring season ( $\mathrm{T}$ 1) without using the BP mulch. In general, average fruit of med, early and total yield were higher when the soil tilled 3 times and covered with BP mulch compared with other treatment combinations. 
Table (1): Some physical and chemical soil characteristics of the experimental site.

\begin{tabular}{|c|c|c|c|c|c|c|}
\hline Texture & pH & $\begin{array}{c}\text { EC } \\
(\mathrm{dS} \text { m-1) }\end{array}$ & $\begin{array}{c}\mathrm{CaCo3} \\
(\%)\end{array}$ & $\begin{array}{c}\text { Organic } \\
\text { matter }(\%)\end{array}$ & $\begin{array}{c}\text { Total N } \\
(\%)\end{array}$ & $\begin{array}{l}\mathrm{NaHCO3} \\
-\mathrm{P}(\mathrm{ppm})\end{array}$ \\
\hline $\begin{array}{l}\text { Sand Clay } \\
\text { Loam }\end{array}$ & 7.91 & 1.58 & 30 & 1.69 & 0.0621 & 22 \\
\hline
\end{tabular}

Table (2): Effects of tillage and mulching on soil moisture content of squash grown under rain-fed conditions.

\begin{tabular}{|c|c|c|c|c|}
\hline \multirow{2}{*}{$\begin{array}{c}\text { Tillage } \\
\text { time }\end{array}$} & \multirow{2}{*}{ Mulch } & \multicolumn{3}{|c|}{ Soil Moisture content (SMC) } \\
\cline { 3 - 5 } & & $(30$ days $)$ & $(60$ days $)$ & $(90$ days) \\
\hline \multirow{2}{*}{ T 1 } & BP Mulch & 23.0 bc* & 18.1 a & 13.0 ab \\
\cline { 2 - 5 } & No mulch & 20.9 c & 15.5 bc & 12.4 ab \\
\hline \multirow{2}{*}{ T 2 } & BP Mulch & $23.9 \mathrm{~b}$ & 16.8 ab & 12.8 ab \\
\cline { 2 - 5 } & No mulch & 21.7 c & $14.3 \mathrm{c}$ & 12.6 ab \\
\hline \multirow{2}{*}{ T 3 } & BP Mulch & 26.5 a & $17.0 \mathrm{a}$ & $13.5 \mathrm{a}$ \\
\cline { 2 - 5 } & No mulch & $21.2 \mathrm{c}$ & $15.0 \mathrm{c}$ & $11.8 \mathrm{~b}$ \\
\hline
\end{tabular}

* Means having different letters within each column are significantly different at $5 \%$ level of probability according to DMRT

Table (3): Effects of tillage and mulching on vegetative growth, germination and flowering times of squash grown under rain-fed conditions.

\begin{tabular}{|c|c|c|c|c|c|}
\hline $\begin{array}{c}\text { Tillage } \\
\text { practices }\end{array}$ & Mulch & $\begin{array}{c}\text { Fresh wt } \\
\text { (gm/plant) }\end{array}$ & $\begin{array}{c}\text { Dry wt } \\
\text { (gm/plant) }\end{array}$ & $\begin{array}{c}\text { Germination } \\
\text { time (days) }\end{array}$ & $\begin{array}{c}\text { Flowering time } \\
\text { (days) }\end{array}$ \\
\hline \multirow{2}{*}{ T 3} & BP Mulch & $607.0 \mathbf{a b}^{*}$ & $66.11 \mathrm{ab}$ & $11.00 \mathrm{c}$ & $38.00 \mathrm{c}$ \\
\hline & No mulch & $487.0 \mathrm{~b}$ & $37.67 \mathrm{~b}$ & $13.22 \mathrm{~b}$ & $40.22 \mathrm{~b}$ \\
\hline \multirow{2}{*}{ T 2} & BP Mulch & $694.2 \mathrm{a}$ & 78.89 a & $11.00 \mathrm{c}$ & $38.00 \mathrm{c}$ \\
\hline & No mulch & $526.4 \mathrm{ab}$ & $40.56 \mathrm{~b}$ & $14.33 \mathrm{a}$ & $41.33 \mathrm{a}$ \\
\hline \multirow{2}{*}{ T 1} & BP Mulch & 713.1 a & 63.33 ab & $11.00 \mathrm{c}$ & $38.00 \mathrm{c}$ \\
\hline & No mulch & $645.3 \mathrm{ab}$ & $41.11 \mathrm{~b}$ & $14.33 \mathrm{a}$ & $41.33 \mathrm{a}$ \\
\hline
\end{tabular}

Table (4): Effect of tillage and mulching on yield of squash grown under rain-fed conditions.

\begin{tabular}{|c|c|c|c|c|c|}
\hline \multirow{2}{*}{$\begin{array}{c}\text { Tillage } \\
\text { practices }\end{array}$} & \multirow[t]{2}{*}{ Mulch } & \multicolumn{4}{|c|}{ Yield distribution (ton/ha) } \\
\hline & & Early & Mid & Late & Total \\
\hline \multirow{2}{*}{ T 1} & BP Mulch & $6.54 \mathrm{bc}^{*}$ & $6.93 \mathrm{bc}$ & $3.23 \mathrm{bc}$ & $16.60 \mathrm{~b}$ \\
\hline & No mulch & $3.63 \mathrm{~d}$ & $2.91 \mathrm{~d}$ & $1.09 \mathrm{~d}$ & $7.63 \mathrm{c}$ \\
\hline \multirow{2}{*}{ T 2} & BP Mulch & $8.66 \mathrm{ab}$ & $9.03 \mathrm{ab}$ & 5.59 a & 23.28 a \\
\hline & No mulch & $5.32 \mathrm{~cd}$ & $4.48 \mathrm{~cd}$ & $1.77 \mathrm{~cd}$ & $11.57 \mathrm{bc}$ \\
\hline \multirow{2}{*}{ T 3} & BP Mulch & 10.34 a & $11.55 \mathrm{a}$ & $6.06 \mathrm{a}$ & 27.95 a \\
\hline & No mulch & $6.08 \mathrm{c}$ & $6.84 \mathrm{bc}$ & $3.70 \mathrm{~b}$ & $16.62 \mathrm{~b}$ \\
\hline
\end{tabular}


Table (5): Effects of tillage and mulching on fruit number of squash grown under rain-fed conditions.

\begin{tabular}{|c|c|c|c|c|c|}
\hline \multirow{2}{*}{$\begin{array}{c}\text { Tillage } \\
\text { practices }\end{array}$} & \multirow[t]{2}{*}{ Mulch } & \multicolumn{4}{|c|}{ Fruit number $\left(1000 \mathrm{ha}^{-1}\right)$} \\
\hline & & Early & Mid & Late & Total \\
\hline \multirow{2}{*}{ T 1} & BP Mulch & 49.7 bc* & 83.9 bc & $42.4 \mathrm{bc}$ & $176.0 \mathrm{~b}$ \\
\hline & No mulch & $38.7 \mathrm{~d}$ & $48.6 \mathrm{~d}$ & $17.5 \mathrm{~d}$ & $104.8 \mathrm{c}$ \\
\hline \multirow{2}{*}{ T 2} & BP Mulch & $62.3 \mathrm{ab}$ & $92.2 \mathrm{ab}$ & 56.8 a & $211.3 \mathrm{a}$ \\
\hline & No mulch & $41.3 \mathrm{~cd}$ & $59.2 \mathrm{~cd}$ & $25.0 \mathrm{~cd}$ & $125.5 \mathrm{bc}$ \\
\hline \multirow{2}{*}{ T 3} & BP Mulch & $72.0 \mathrm{a}$ & $111.3 \mathrm{a}$ & $67.5 \mathrm{a}$ & 250.8 a \\
\hline & No mulch & $47.9 \mathrm{c}$ & 74.3 bc & $45.3 \mathrm{~b}$ & $167.5 \mathrm{~b}$ \\
\hline
\end{tabular}

Table (6): Effects of tillage and mulching on average fruit weight of squash grown under rain-fed conditions.

\begin{tabular}{|c|c|c|c|c|c|}
\hline \multirow{2}{*}{$\begin{array}{c}\text { Tillage } \\
\text { practices }\end{array}$} & \multirow[t]{2}{*}{ Mulch } & \multicolumn{4}{|c|}{ Average fruit weight (g) } \\
\hline & & Early & Mid & Late & Total \\
\hline \multirow{2}{*}{ T 1} & BP Mulch & $131.6 a^{*}$ & $82.5 \mathrm{~b}$ & 76.2 bc & $94.3 \mathrm{c}$ \\
\hline & No mulch & $93.7 \mathrm{~b}$ & $59.8 \mathrm{~d}$ & $62.3 \mathrm{c}$ & $72.8 \mathrm{~d}$ \\
\hline \multirow{2}{*}{ T 2} & BP Mulch & $139.0 \mathrm{a}$ & $97.9 \mathbf{a}$ & $98.4 \mathrm{a}$ & $110.2 \mathrm{ab}$ \\
\hline & No mulch & $128.8 \mathrm{a}$ & $75.6 \mathrm{c}$ & $70.8 \mathrm{c}$ & $92.2 \mathrm{c}$ \\
\hline \multirow{2}{*}{ T 3} & BP Mulch & 143.6 a & 103.8 a & 89.8 a & 111.4 a \\
\hline & No mulch & 126.9 a & $92.1 \mathrm{~b}$ & $81.7 \mathbf{a b}$ & 99.2 bc \\
\hline
\end{tabular}

* Means having different letters within each column are significantly different at $5 \%$ level of probability according to MRT

\section{DISCUSSION}

Soil water content (SMC) was significantly higher in plots covered with black plastic mulch than non covered plots. It means that black plastic mulch reduced soil water evaporation and thus helps retain soil water. The combination of mulching with tillage in conserving soil moisture has been recognized by many researchers (Hatami et al., 2012; Singh and Kamal, 2012; Mamkagh, 2009; Anikwe et al., 2007; Grevers et al., 1986; Bhagat and Acharya, 1987; Sarkar and Singh, 2007).

Ramakrishna et al. (2006) reported that evaporation from the soil accounts for $25-50 \%$ of the total quantity of water used. Covering the soil with plastic mulch reduced soil water evaporation, and thus helps retain soil moisture (Mamkagh, 2009; Ogban et al., 2008; Ramakrishna et al., 2006). Data of soil moisture content 30 days after planting indicated that plastic mulch plots contained more water than the unmulched plots.

Nearly, similar trend was noticed at 60 and 90 days after planting while the difference in soil moisture storage was reduced. The amount of moisture stored in the profile to a soil depth of $30 \mathrm{~cm}$ was significantly higher under BP mulch over bare soil. Similar results were obtained by Mamkagh, (2009) and Ramakrishna et al. (2006) who reported that optimum soil moisture ensures good emergence and seedling growth during early and mid season. Also, higher soil moisture content increased root proliferation and thus enhanced availability of nutrients to crop roots (Mamkagh, 2009; Ogban et al., 2008; Sharma et al., 1990). These figures also imply that greater moisture availability to mulched crop during the growing season helped to cope better with drought in mid and late season drought. Douglas and Mckyes (1983) reported that the influence of tillage methods on crop growth and yields is manifested through changes in the soil structure and soil moisture depletion patterns during the growing season. Mulching the soil surface favorably influences the soil moisture regime by controlling evaporation from the soil surface (Mamkagh, 2009; Pawar et al., 2004), and facilitates condensation of soil water at night due to temperature reversals (Tisdall et al., 1991). Mulches also promote crop development and early harvest, and increase yields. Squash growth parameters showed a significant increase in mulched plots compared with non covered plots.

Khattak et al. (2006) indicated that inappropriate tillage and improper timing of field operations caused subsoil compaction, which reducesd $41 \%$ of the water and nutrient use efficiencies by crops. These might decrease soil productivity and crop yields. Also, Jones and 
Sing, (2000) and Jones, (2000) reported that tillage benefits are directly related to soil moisture conservation and available moisture during the growing season. Also, certain tillage management practices could improve some soil physical properties and soil fertility and increase the conservation of soil moisture (Abu-Hammad and Battikhi, 1995).

From the results of the present study, it was concluded that soils tilled three times and covered with plastic mulch produced more vigorous plant and high yield compared with other treatments.

\section{REFERENCES}

Abu-Hammad A. Y., and Battikhi A. M. (1995). Tillage residue management practices, soil moisture, and crop yield in rainfed areas of Jordan. Dirasat, 23 (2): 445-462

Aikins S. H. M. and Afuakwa J. J. (2010). Effect of different tillage practices on cowpea performance. World J. Agric. Sci. 6 (6): 644-651.

Anikwe M. A. N., Mbah C.N., Ezeaku P.I. an Onyia V.N. (2007). Tillage and plastic mulch effects on soil properties and growth and yield of cocoyam (Colocasia esculenta) on an ultisol in southeastern Nigeria. Soil Till. Res., 93 (2): 264-272

Berihun B. (2011). Effect of mulching and amount of water on the yield of tomato under drip irrigation. J. Hort. \& Forest. 3 (7): 200-206.

Bhagat R. M., and Acharya C. L. (1987). Effect of soil management on rainfed wheat in northern India. I. Hydro-thermal regime and root growth. Soil Till. Res., 9: 65-77

Black C. A. (1965). Methods of Soil Analysis: Part I Physical and Mineralogical Properties, American Society of Agronomy, Madison, WI, USA.

De Costa W. A. J. M., Dennet M.D., Ratnaweera U. and Nyalemegbe K. (1997). Effects of different water regimes on field-grown determinate and indeterminate faba bean (Vicia faba L.). I, canopy growth and biomass production. Field Crop Research, 49: 83-93

Department of Meteorology (1997). Internal Report Jordan.

Douglas E. and Mckyes E. (1983). Tillage practices related to limiting plant growth factors and crop growth. Canadian Agric. Eng. 25 (1): 47-55.

Grevers M.C., Kirkland J.A., Jong E. De and Rennie D.A. (1986). Soil water conservation under zero and conventional tillage systems on the Canadian prairies. Soil Till. Res., 8: 265-276.

Gupta J.P and Gupta G.K. (1986). Effect of tillage and mulching on soil environment and cowpea seedling growth under arid conditions. Soil and Till. Res., 7(3):233240.

Hatami S., Nourjou A., Henareh M. and Pourakbar L. (2012). Comparison effects of different methods of black plastic mulching and planting patterns on weed control, water-use efficiency and yield in tomato crops. Int1. J. Agric. Sci.2(10): 928-934.

Jones M. J. (2000). Comparing of conservation tillage systems in barley-based cropping systems in northern Syria, Exp. Agric. (Camb.), 36: 15-26.

Jones M. J. and Sing M. (2000). Long-term yield patterns in barley-based cropping systems in Northern Syria. 2. The role of feed legumes, J. Agric. Sci. (Camb.), 135: $237-$ 249.

Khatibu A. I., Lal R. and Jana R. K. (1984). Effects of tillage methods and mulching on erosion and physical properties of a sandy clay loam in an equatorial warm humid region. Field Crops Research, 8: 239-254.

Khattak M., Khan M.J. and Saleem M. (2006). Impact of various tillage practices on soil moisture content, bulk density and soil strength on clay loam soil condition under rod-kohi area of D.I. Khan. Sarhad J. Agric. 22 (1): 61-69.

Khurshid K., Iqbal M., Arif M. S. and Nawaz A. (2006). Effect of tillage and mulch on soil physical properties and growth of maize. Int1. J. Agric. Biol. 5:593-600.

Kouwenhoven J. K., Perdok U.D., Boer J., Omen G.J.M. (2002). Soil management by shallow mouldboard ploughing in the Netherlands. Soil Till. Res., 65: 125-139.

Mamkagh A. M. A. (2009). Effect of tillage time and black plastic mulch on growth and yield of okra (Abelmoschus esculentus) grown under rain-fed conditions. Intl. J. Agric. Biol. 11:453-457.

Mohler Ch. L. and Callaway M. B. (1995). Effects of tillage and mulch on weed seed production and seed banks in sweet corn. J. Appl. Ecol., 32 (3): 627-639.

Mondal N. A., Hossain S. M. A., Bhuiya S.U. and Jahiruddin M. (2008). Productivity of rainfed mustard in relation to tillage and mulching. Banl. J. Agri. Res. 33(3): 597606. 
Mosaddeghi M. R., Mahboubi A. A. and Safadoust A. (2009). Short-term effects of tillage and manure on some soil physical properties and maize root growth in a sandy loam soil in western Iran. Soil \&Till. Res. 104 (1): 173-179.

Ogban P.L., Ogunewe W.N., Dike R.L., Ajaelo A.C., Ikeata N.I., Achumba U.E. and Nyong E. E. (2008). Effect of tillage and mulching practices on soil properties and growth and yield of cowpea (Vigna unguiculata L. Walp) in southeastern Nigeria. Agro-science, J. Trop. Agric. 7 (2): 118-128.

Pawar S.N., Divekar S.P., Ghule S.B., and Kadale A. S. (2004). Effect of mulching on moisture conservation and yield of summer groundnut. J. Soil Crops, 14 (2): 410-413.

Pilbeam C. J., Hebblethwaite P. D., Nyongesa T. E. and Ricketts H. E. (1991). Effects of autumn sowing dates on growth and yield of determinate and indeterminate field beans (Vicia faba L.). J. Agric. Sci., 116:385-393.

Ramakrishna A., Hoang M.T., Suhas P. W. and Tranh D. L. (2006). Effect of mulch on soil temperature, moisture, weed infestation and yield of groundnut in northern Vietnam. Field Crops Res., 95 (2-3): 115-125.
Sarkar S. and Singh S.R. (2007). Interactive effect of tillage depth and mulch on soil temperature, productivity and water use pattern of rainfed barley (Hordium vulgare L.). Soil Till. Res., 92: 79-86.

Sharma P.K., Kharwara P.C. and Tewatia R.K. (1990). Residual soil moisture and wheat yield in relation to mulching and tillage during preceding rainfed crop. Soil Till. Res., 15 : 279-284

Sing A.K. and Kamal S. (2012). Effect of black plastic mulch on soil temperature and tomato yield in mid hills of Garhwal Himalayas. J. Hort. \& Forest. 4 (4): 78-80.

Steel R. G. D. and Torrie J. H. (1980). Principles and Procedures of Statistics: A Biometrical Approach, $2^{\text {nd }}$ edition. McGraw-Hill, New York.

Thompson R. and Taylor H. (1982). Prospects for Vicia faba L., in Northern Europe. Outlook Agric. 11: 127-133.

Tisdall J.A., Baverly R.D., and Radcliffe D.E. (1991). Mulch effect on soil properties and tomato growth using micro-irrigation. Agron. J., 83: 1028-1034.

Varco J.J., Frye W.W., Smith M. S. and MacKown C.T. (1989). Tillage effects on nitrogen recovery by corn from a nitrogen15 labeled legume cover crop. Soil Sci. Soc. Am. J., 53: 822-82.

\section{دراسة تأثير الحراثه والملث البلاستيكي الأسود على نمو وإنتاجية محصول الكوسا تحت ظروف الزراعة البعلية في المناطق شبه الجافي البافة}

$$
\text { قسم الإنتاج النباتي ـ كلية الزراعة ياسين جامعة مؤتهــ الكرك ـ الأردن }
$$

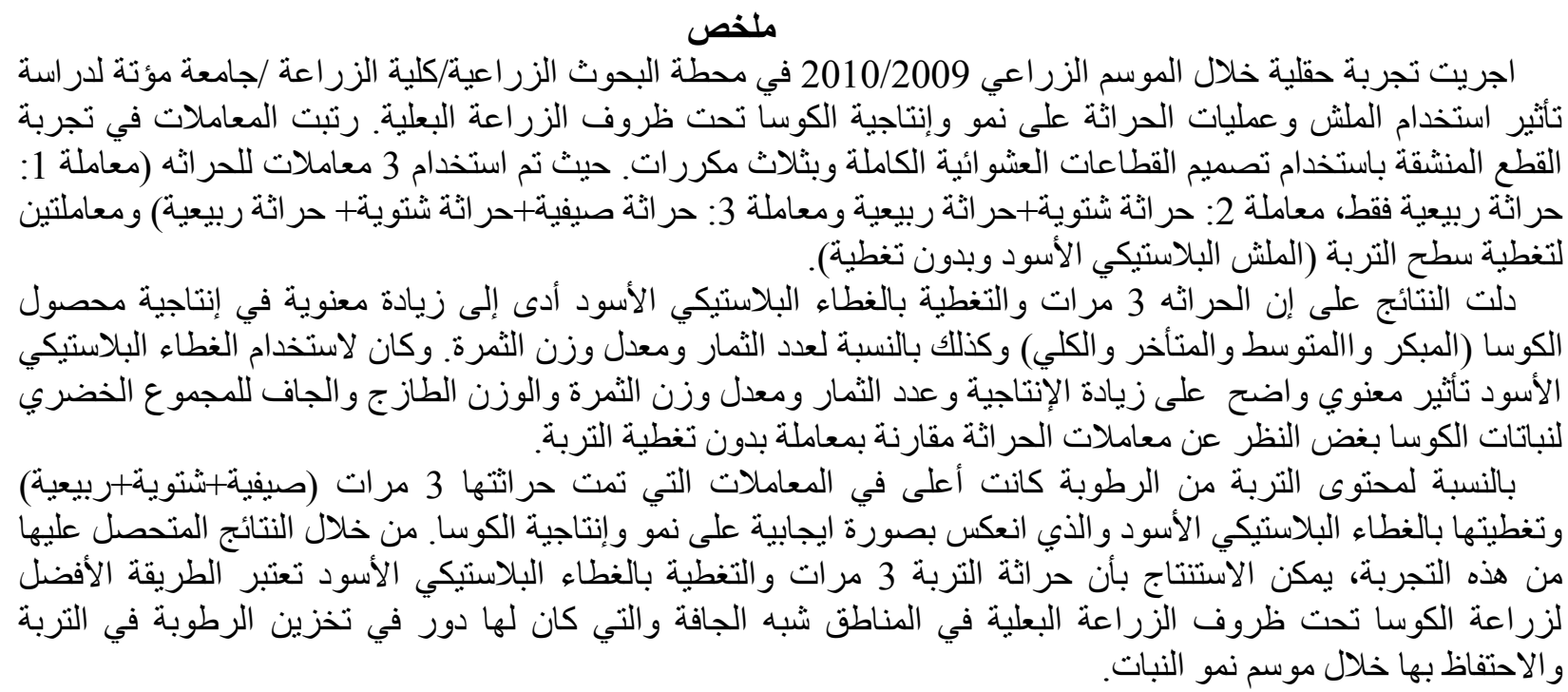
المجلة العلمية لكلية الزراعة - جامعة القاهرة - المجلا (64) العدد الرابع (أكتوبر2013):437-443. 